\title{
The Effect of Video Project-Based Learning on Students' Critical Thinking Skills during the Covid- 19 Pandemic
}

\author{
Albi Anggito 1 , Pratiwi Pujiastuti 2, Dhiniaty Gularso 3 \\ DOI: $10.35445 /$ alishlah.v13i3.772
}

Article Info Abstract

Keywords:

Proiect-basedlearning;

Critical Thinking;

Social Science

Keywords:

Project-basedlearning;

Berpikir Kritis;

IPS

Project-based learning using video is being used at the University of Yogyakarta in order to examine the impact on students' thinking skills. The Paired Sample ttest analytic method was employed in this study to conduct a quasi-experiment, which is described in detail below. The findings revealed that: 1) the average increase from the pretest score to the posttest score was 4.55 in the experimental class and 3.41 in the control class, and 2) a statistically significant difference in the average increase was observed in the experimental class when the Projectbased learning model was used in the classroom. The experimental class uses Project-based Learning, 3) the data in the experimental class is 0.097 (pretest) and 0.062 (posttest). In contrast, the data in the control class is 0.083 (pretest) and 0.064 (posttest), 4) the results of the hypothesis test revealed a significance level of 0.007 in the experimental class and 0.016 in the control class, both of which were less than the significance level of 0.005 , so that Ho was rejected and $\mathrm{H} 1$ was accepted. According to the findings of this study, there appears to be an effect of applying the Project-based learning model on students' critical thinking skills in social studies classes. PjBL (project-based learning) models that include video can help students substantially enhance their critical thinking skills.

Abstrak
Penelitian ini memiliki tujuan untuk mengetahui pengaruh model Project-based
learning dengan video terhadap kemampuan berpikir kritis mahasiswa. Metode
yang digunakan dalam penelitian ini yakni eksperimen semu dengan
menggunakan metode analisis Paired Sample T-Test (Uji T). Hasil penelitian
mennunjukkan 1) terdapat kenaikan rata-rata dari skor pretest dengan skor
posttest yakni 4,55 pada kelas ekspersimen dan 3,41 pada kelas kontrol, 2)
perbedaan kenaikan rata-rata yang signifikan terlihat pada kelas eksperimen
yang menggunakan model pembelajaran Project-based learning, 3) data pada
kelas eksperimen sebesar o,o97 (pretest) dan o,062 (posttest) sementara kelas
kontrol o,o 83 (pretest) dan o,o64 (posttest) sehingga kedua data kelas tersebut
telah berdistribusi normal, 4) hasil pada uji hipotesis menunjukkan nilai Sig.
sebesar o,o07 pada kelas eksperimen dan o,o16 pada kelas kontrol, keduanya
kurang dari nilai sig o,o05 sehingga $\mathrm{H}_{0}$ ditolak dan $\mathrm{H}_{1}$ diterima. Dapat
disimpulkan bahwa terdapat pengaruh penggunaan model pembelajaran
Project-based learning terhadap kemampuan berpikir kritis mahasiswa pada
mata kuliah IPS. Model PjBL (Project-based learning) dengan video dapat

\footnotetext{
${ }^{1}$ Un iv ersitas Negeri Yogyakarta, Yogyakarta, In donesia

Em a il: albianggito.2020@student.uny.ac.id

2 Un iv ersitas Negeri Yogyakarta, Yogyakarta, In donesia,

Em ail:pratiwi@uny.ac.id

3 Un iv ersitas PGRIYogyakarta,Yogyakarta, In donesia

Em ail: dhiniaty@upy.ac.id
} 
berpengaruh secara signifikan untuk meningkatkan kemampuan berpikir kritis mahasiswa.

\section{INTRODUCTION}

Primary education, secondary education, and postsecondary education rely heavily on the teaching and learning processes to carry out their missions. An essential part of the teaching and learning process is a sequence of teacher-student interactions that are mutually beneficial to attain specified goals. The teacher-student relationship becomes a critical pillar of the educational process. In addition, the success of the teaching and learning process depends critically on the exchange or reciprocal interaction between professors and students (Razaq, 2014). Innovation in education is essential, especially when it is linked to technological, information, and communication advancements (ICT). As a result, ICT development has become an integral component of human life, including education, and this is why this is happening (Suradji, 2018). It is envisaged that an ICT-integrated innovation will improve learning quality and, as a result, help students attain their educational goals. Educational technology aims to make the learning process more effective and efficient (Andri, 2017).

Indonesian educators must be able to establish an effective learning environment for students to attain educational quality standards, as mandated by the Indonesian National Qualifications Framework curriculum and considerations of parts of the 4.0 industrial revolution (Ancient, 2019). This is critical, given that national education quality standards are always working to raise the bar. In addition to the National Standards for Education and Research and Community Service, the National Standard for Higher Education is a standard unit (Kemenristekdikti, 2014). It is not just the learning process that teachers focus on while using the IQF curriculum to conduct instruction but also the evaluation of learning. Because of this, each university's academic programs must produce high-quality courses for students in their particular majors at the tertiary level.

Social science is a simplification or adaptation of the disciplines of social sciences and humanities and basic human activities organized and presented scientifically and pedagogically/psychologically for educational purposes (Jaenudin, 2014). From this opinion, it can be interpreted that social studies integrate various comprehensive social science disciplines, so it cannot be seen only through one social science lens. Social Sciences also emphasizes individual skills in solving problems ranging from self to complex issues (Supardi, 2012). Humans always face issues related to various aspects within the area of social science and outside the social sphere. Through social studies, it is hoped that individuals can solve social problems around them and provide alternative solutions that can be used to resolve conflicts in society.

Individuals who study social studies are preparing themselves to become citizens who can solve their own issues and those of others and the ability to make decisions and participate in society. As a good citizen, one must participate in various social activities (Basyarudin, 2019). Mutakin (Supardi, 2012) stated that the goal of social studies education is to help students become more socially aware, capable of confronting and solving their own personal problems as well as those of society, and able to pass on positive cultural traits like the shared values, norms, and practices of a community.

The reality in the field, instead of being a subject that develops the above abilities, is in fact that Social studies are still considered to be loaded with memorization and a lot of material. So that important skills such as critical thinking are often rarely honed. Social studies learning, which is expected to be interpreted by students, becomes a tedious and less exciting subject to listen to. The ability to think critically, which should be a weapon to explore more knowledge, is still an ability that students show. The ability to think critically is quite unique because, in Bloom's Taxonomy, it has been included in the $\mathrm{C}_{4}$ category (analyzing level). 
In the context of critical thinking, evaluating a statement's truth is a mental exercise that finishes with a decision to accept, deny, or dispute the statement's reality (Zubaidah, 2010). An indicator is a measure of a condition that can be used to monitor changes in an event or activity. You can use a hand to gauge a person's critical thinking capacity. The following are some key indications of thinking: Possess a thorough understanding of all aspects of an issue and be able to identify the information needed to solve it. Possess a thorough understanding of all aspects of a problem, and be able to identify the information needed to solve it (Ennis, 1993). According to other scholars, critical thinking is characterized by the following characteristics: For a person to be able to effectively assess information, synthesize it, solve issues, and conclude, they must have the following skills: Experts who have studied critical thinking skills have determined that the following are indicative of someone's ability: First, doing a thorough investigation of the issue, then uncovering alternative solutions, then determining a path out of it, and last, deciphering the longterm effects (Angelo, 1995).

The results of the initial needs analy sis also show that student learning outcomes need to be a concern. This is due to the level of activeness and critical thinking skills of students who are still not well-honed. Alternative efforts to overcome these problems are certainly needed. One of the potential learning models to be used to improve students' critical thinking skills is project-based learning (PjBL). Project-based learning models can be used to motivate individuals to apply active critical thinking skills in project planning, collaborative problem solving, and higher-order thinking (Turner, 2012). Learning that adopts this model is constructivism-based learning by introducing real-life situations into the school environment (Habók \& Nagy, 2016). More specifically, other experts argue that this method will emphasize students managing learning by providing a project for students (Sani, 2013).

Previous research related to implementing the project-based learning model in high school shows that the PjBL model can motivate students to be enthusiastic about learning and students' knowledge. This is because students memorise and are also able to understand it ( $\mathrm{Dj}, 2017)$. The research illustrates that video project-based learning can increase students' desire to learn. Other research also shows that video project-based learning can improve student learning outcomes (Lugiati, 2020). Video is able to summarize various events in a long time to be more concise and dense. The presence of images and sounds that can be watched again makes it easier to re-observe the events or arguments contained in the video. Apart from being implemented in high school, the video-assisted project-based learning model has also been implemented for elementary school students to increase the creativity of works of art. This study concluded that the application of the video-assisted PjBL model could increase the creativity of elementary school students' artwork (Handayani \& Dian, 2021). Applying the PjBL model through various outcomes introduced early will foster an initial perception of identical tasks in the future. The cultivation of thinking patterns with the PjBL model's help is undoubtedly expected to be correlated so that students continue to higher levels, such as universities.

There is a significant relationship between students' perception of the application of the learning model with learning achievement. A good perception of the application of a learning model has a significant impact on learning achievement. However, it is necessary to do refraction in learning (Effendi, 2015). Therefore, in another study related to student perceptions of applying the video project-based learning model, the results were obtained in a good category (30\% very good and 70\% good) in learning (Adinugraha, 2018). So that in the application of this research, the implementation of the Learning Media lecture uses the Project-Based Learning model from meeting 1 to meeting 16 with the hope that students will become familiar with the model.

For the first time, students are given the freedom of expression to make their own video works. Students also have complete control over the platforms and tools they utilize to create movies. Focus is on the critical topics that students are studying and critiquing to emerge logical 
and accountable arguments. In addition, students are obliged to post their videos on social media platforms such as WhatsApp's Story, Instagram, YouTube, and Twitter in order to make them more accessible to a wider audience. Students' interests and the evolution of the times are considered while selecting video material for project-based learning objectives (David et al., 2017). The video includes audio-visual learning media with various advantages in helping the learning process. Especially during a pandemic like today, video is a medium that can be quickly disseminated and shared anywhere and anytime as long as you have a good device and network. Video can also be used as a medium to improve critical thinking skills and student achievement (Utomo \& Wihartanti, 2019).

Using video as a medium for arguing is advantageous since it can help an individual's critical thinking when he is confronted with a real-world visual (Warsito, 2008). Students are able to express and develop their ideas through films freely. To prepare for the interview, they are encouraged to think critically about their beliefs. Students' critical thinking abilities are predicted to increase due to using a Project-based learning paradigm that includes student videos that reflect their perspectives on issues in the local community. Because of this, educator researchers combine to perform experimental research on the impact of video project-based learning on students' critical thinking abilities.

\section{METHOD}

This study uses a quantitative research approach with the type of Quasi-Experimental. Experimental research is research to find out whether there is a result of "something" imposed on the subject under investigation, in other words knowing whether there is a causal relationship (Arikunto, 2010). The research design used in this study is the Non-Equivalent Control Group Design with the following pattern.

\begin{tabular}{|c|c|c|}
\hline O1 & $\mathrm{X}$ & O2 (experimental) \\
\hline $\mathrm{O} 2$ & & $\mathrm{O}_{4}$ (control) \\
\hline
\end{tabular}

Information:

O1 : the pretest value of the experimental class (before being given treatment)

$\mathrm{O} 2$ : the posttest value of the experimental class (after being given treatment)

$\mathrm{O} 3$ : the control pretest value (before treatment)

$\mathrm{O} 4$ : the control class posttest scores (without treatment)

$\mathrm{X}$ : treatment given

(Sugiyono, 2016)

The subjects in this study were primary school teacher education students in Yogyakarta, which was held from March 3, 2021, to May 30, 2021. In this study, class A6 was used as an experimental class of 37 students and class A8 as a control class of 37 students. The practical class uses a Project-based learning model, while the control class uses a problem-based learning model. Both classes will produce products in posters, and poster scores will be analyzed using the T-Test with the SPSS 20 program. Lecture activities in the experimental class and control class follow the syntax according to their respective learning models.

The experimental class uses the Project-based learning (PjBL) learning model following the syntax or learning steps, namely 1) pre-project carried out by designing project descriptions, determining project milestones, preparing media and various learning resources, and preparing learning conditions, 2 ) phase 1 identifies the product, namely observing particular objects and then students identify problems and formulate problems in the form of questions, 3) phase 3 
conducts research, namely students collect data and analyze, 4) phase 4 compiles a product draft or prototype as an initial product design based on the results of the research, 5) phase 5 measures, assesses, and improves the product, namely looking back at the initial product that was made to find its shortcomings and improve it again,6) phase 6 finalization and product publication, where students finalize the product after it is believed to be published, and 7) post-project, namely practicing (lecturers) assessing, providing reinforcement, input, and suggestions on products that have been produced by students (Abidin, 2016).

Meanwhile, the control class uses a Problem Based Learning (PBL) learning model with syntax steps, namely 1) student orientation to the problem and being briefed on the focus of the problem to be studied, 2) organizing students to learn means that students will be directed to study more deeply about the problem. That has been found, 3) guiding individual and group investigations, in this stage monitoring the problem assessment process carried out by students, 4) developing and presenting the work, and 5) analyzing and evaluating the problem-solving process.

Descriptive analysis is calculated by comparing the average value of each variable with the normal curve criteria. The analysis prerequisite test used the data normality test. Meanwhile, in hypothesis testing, after testing, the analysis requirements are met because there are only two groups. The hypothesis test used is the T-test.

Hypothesis testing is done by using the Independent Sample T-test analysis in the SPSS program. The decision making is done by comparing the value of tcount with ttable with the following conditions:

a. If $\pm t_{\text {count }}< \pm t_{\text {table, }}$, then $\mathrm{H}_{\mathrm{o}}$ is accepted and $\mathrm{H}_{\mathrm{a}}$ is rejected

b. If $\pm t_{\text {count }}> \pm t_{\text {table, }}$, then $H_{o}$ is rejected and $H_{a}$ is accepted.

In addition, by using a significance level of $5 \%$ and carried out using SPSS software, the basis for making decisions to accept or reject the hypothesis in the independent sample t-test is as follows:

a. If the probability (Asymp.Sig) $<0.05$, then $\mathrm{H}_{\mathrm{o}}$ is rejected, meaning there is a difference.

b. If the probability (Asymp.Sig) $>0.05$, then $\mathrm{H}_{\mathrm{o}}$ is accepted, meaning no difference.

\section{FINDINGS AND DISCUSSION}

Critical thinking skills were measured in both the experimental and control classes, as well as in pre-and posttests. The results of the normality tests and the $\mathrm{T}$-test were also included in this study's findings. The SPSS 20 program was used to perform the normality and T-tests.

Table 1. Student Critical Thinking Score

\begin{tabular}{llll}
\hline Class & Pretest & Posttest & Difference \\
\hline Experiment & 45.27 & 49.82 & $\mathbf{4 . 5 5}$ \\
Control & 45.62 & 49.03 & $\mathbf{3 . 4 1}$ \\
\hline
\end{tabular}

Based on the calculation of students' critical thinking scores in the experimental class, there was an increase of 4.55 points, from the average pretest score of 45.27 to 49.82 in the posttest. On the other hand, the control class also experienced a rise of 3.92 points, with an average pretest score of 45.62 to 49.03 in the posttest score. 


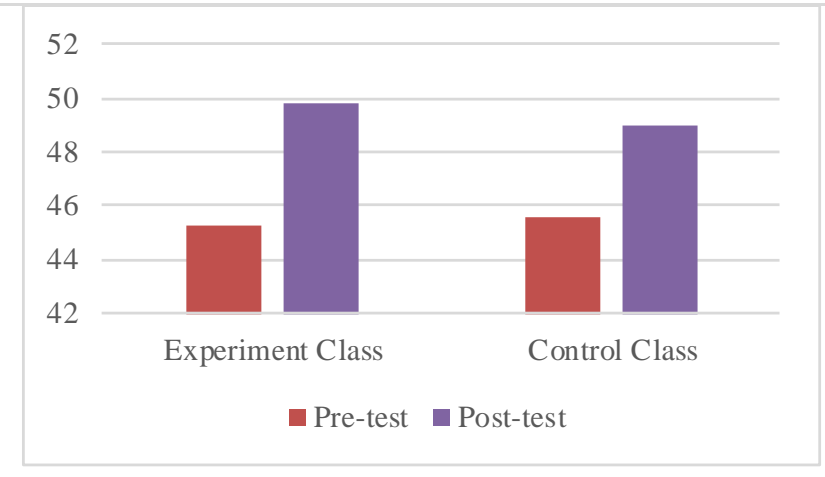

Figure 1. Students' Critical Thinking Score

Next, the data from the normality test in the experimental and control classes continued with the data from the T-test to get conclusions from the research hypothesis.

Table 2. Normality Test for Experimental Class

\begin{tabular}{lllllll}
\hline & \multicolumn{2}{l}{ Kolmogorov-Smirnova } & \multicolumn{3}{l}{ Shapiro-Wilk } \\
\cline { 2 - 7 } & Statistics & df & Sig. & Statistics & df & Sig. \\
\hline Pretest & .133 & 37 & .097 & .894 & 37 & .002 \\
Postest & .141 & 37 & .062 & .932 & 37 & .025 \\
\hline
\end{tabular}

a. Lilliefors Significance Correction

In the normality test results, the experimental class data showed that the sig value in the pretest was 0.097 and 0.062 at the posttest. Both sig values in the experimental class were more than 0.05 so that the data was declared normally distributed. In addition to the experimental class normality test, the following are the control class normality test results.

\section{Table 3. Normality Test for Control Class}

\begin{tabular}{lllllll}
\hline & \multicolumn{3}{l}{ Kolmogorov-Smirnova } & \multicolumn{3}{l}{ Shapiro-Wilk } \\
\cline { 2 - 7 } & Statistics & df & Sig. & Statistics & df & Sig. \\
\hline Pretest & .136 & 37 & .083 & .891 & 37 & .002 \\
Postest & .140 & 37 & .064 & .890 & 37 & .002 \\
\hline
\end{tabular}

a. Lilliefors Significance Correction

The normality test results of the data in the control class were the sig value in the pretest of 0.083 and 0.064 in the posttest, both of which were also more than 0.05. Therefore, the data in the control class is normally distributed. After the normality test, the next step is to test the hypothesis using the Paired Sample T-Test with the following results

Table 4. Paired Sample T-Test Experiment Class and Control Class

Paired Sam ples Test

\begin{tabular}{cccccccc}
\hline & & \multicolumn{9}{c}{ Paired Differences } & df & Sig. (2-tailed) \\
\cline { 2 - 8 } & & mean & Std. Dev & Std. Error & Mean & t & \\
\hline P1 & Pre-pos & $-4,349$ & 2.163 & .356 & -13.071 & 36 & .008 \\
\hline P2 & Pre-pos & $-3,719$ & .722 & .119 & -33.026 & 36 & .016 \\
\hline
\end{tabular}

The result of the value of Sig. (2-tailed) The experimental class is 0.008, and the control class is 0.016 . This value is smaller than 0.05 . Thus, it means that $\mathrm{H}_{\mathrm{o}}$ is rejected and $\mathrm{H}_{1}$ fails to be rejected. Differences also influence the difference in students' critical thinking results in the use of learning models in the control class and the experimental class. The control class uses a problembased learning model, and the experimental class uses a project-based learning (PjBL) model. The results show that the project-based learning model has a greater influence on students' critical thinking skills. 
The calculation of the critical thinking ability score of students in the experimental class showed an increase of 4.56 points, with an average pretest score of 45.27 to 49.82 in the posttest. Meanwhile, the control class experienced an increase of 3.41 points, with an average pretest score of 45.62 to 49.03 in the posttest score. Furthermore, seen from the normality test results, the experimental class data has a sig value of 0.097 in the pretest and 0.062 in the posttest. Both sig values in the practical class are more than 0.05 , so that the data is normally distributed. The normality test results of the control class data, namely the sig value in the pretest of 0.083 and 0.064 in the posttest, are also more than 0.05 so that the data in the control class is normally distributed. After the normality test, proceed with hypothesis testing using the Paired Sample TTest with the results of the Sig value. (2-tailed). The experimental class is 0.008 , and the control class is 0.016 . The value is smaller than 0.05. Thus it means that Ho is rejected and $\mathrm{H} 1$ fails to be rejected, the difference also influences the difference in students' critical thinking results in the learning model used, from these results, the project-based learning model has a greater influence on students' critical thinking skills.

Based on the research data obtained, it shows a significant effect on the use of the Projectbased learning model on the critical thinking skills of students in the Social Sciences 1 course. The existence of this influence cannot be separated from the stages of implementing the model in class. The first stage, namely the project planning stage (project planning). At this stage, students must determine the project's theme and formulate guiding questions (driving questions) that will evaluate students in designing or implementing future project-making processes. Critical thinking skills developed by students at this stage include skills in formulating problems and hypothesizing, which aims to make students learn to formulate them in the form of questions in order to provide directions for providing logical and critical arguments based on the chosen theme. This is by the opinion Ledward, BC, \& Hirata (2011) explained that through the project, students would be trained to face the world of work that requires their ability to access, synthesize, communicate information and work together to solve complex problems.

In the second stage of project implementation (project launch), students' critical thinking skills will be further developed through the process of searching for sources or information relevant to the project theme. Critical thinking is not only able to prove a certain purpose, interpret, and solve problems, but critical thinking can be done collaboratively and competitively.(Facione, 2015). Students who have critical thinking skills will be very beneficial when they encounter a problem or want to develop a topic. This is because these students can think innovatively and reflectively. It is in line with another expert who also explained that Project-Based Learning (PjBL) is one of the innovative approaches in learning that teaches multi-strategies critical for student success in the 21st century (Bell, 2010).

In the third stage of guided inquiry and product creation (guided inquiry and product creation), researchers play a role in facilitating students' use of resources in conducting investigations and making products. Learning carried out in the Project-based learning model is believed to develop critical thinking skills and learning creativity in students to understand concepts and problem-solving skills contextually through investigation and project creation (Rosma \& Hasanah, 2021). Therefore, with the PJjBL model with video, students will proceed to develop their critical thinking skills through making project products.

In the fourth stage, project conclusion, Project-based learning (PjBL) can improve critical thinking skills through activities to seek information from various sources, help understand the discussion more profoundly and consider different views. In addition, PjBL encourages active investigation, explores a problem from multiple perspectives, and learns how to ask related issues, gather information, solve problems, and be accountable for the results of their presentations (Susanawati et al., 2013). The existence of feedback from students and the ability to present projects made a stimulus for students to develop critical thinking skills. 
Critical thinking can be implemented in several activities, such as a) lectures, b) laboratories, c) homework, d) several exercises, e) papers, and f) exams (Mustaji, 2015). Therefore, thinking skills for students can be internalized in the curriculum by considering several aspects, including 1) who teaches, 2) what is taught, 3) when to teach, 4) how to teach, 5) how to evaluate, 6) conclude. Video-based project-based learning is certainly an alternative that can be used to develop students' critical thinking skills.

The project carried out is a video with the theme of potential and problems related to the scope of social studies in the student community. Educators can also improve students' critical thinking by giving examples related to the material(Yunita et al., 2018). This project is given to provide an opportunity to be sensitive to the environment, attempt to analyze problems, cause and effect, and alternative solutions to problems posed by students on topics discussed critically. Critical thinking aims to solve problems, formulate conclusions, calculate possibilities, and make decisions (Hasan \& Kazazi, 2014). In providing this alternative solution, students are asked first to review the literature related to their study. Videos must go through the syntax in $\mathrm{PjBL}$ to provide constructive thinking schemes for students, so it can be concluded that PjBL has a significant effect on students' critical thinking skills.

This research is relevant to several previous studies, such as Project-based learning to Develop Student Creativity Designing Counseling Information Media through Social Media. The similarity with this research is the use of the PjBL learning model (Suryahdikusumah, 2018). The second research, about improving the critical thinking ability of UMM Biology Education Students through lesson study, has similarities in using PjBL learning models related to students' critical thinking skills (Wahyuni et al., 2015). Another relevant research about improving students' critical thinking skills in science education courses using the Project-Based Learning Model has similarities in the use of the PjBL model to enhance critical thinking, but by using Classroom Action Research. The results obtained that the project-based learning model can improve students' critical thinking skills (Mulia \& Mustadi, 2019).

Based on the literature review and research results obtained, Project-based learning becomes a potential alternative to be used by educators to develop students' critical thinking skills because they are stimulated by syntax that involves physical and psychological (thinking) activities. Projectbased learning provides students with activities that seem to exist in the real world to produce a more realistic output(Sari \& Angreni, 2018). Project-based learning also allows each individual to imitate what scientists do, exciting and fun if appropriately implemented (Insyasiska et al., 2015). Therefore, this model is highly recommended in limited circumstances, such as during the current Covid-19 pandemic.

\section{CONCLUSION}

Project-based learning has a considerable impact on students' critical thinking abilities, according to the results and discussions offered. In part, this is because the stages of this learning paradigm involve tasks that help students think at a higher and deeper level. Social studies classes necessitate authentic learning and the opportunity to present arguments based on solid research so that students may better comprehend the content being addressed in a more credible and grounded manner. Social studies can also help students improve their critical thinking skills by focusing on the environment around them, which focuses on the class. Students in social studies classes can benefit from using the Project-based learning paradigm. Researchers have concluded that Project-based learning model may be utilized to develop students' critical thinking skills, and educators need to understand and use it to accomplish their aims. On the other hand, projectbased learning is not a model that can immediately have a direct influence but one that needs to be implemented consistently and evaluated. 


\section{REFERENCES}

Abidin, Y. (2016). Learning System Design in Curriculum Context. Aditama Refika.

Adinugraha, F. (2018). Project-Based Learning Model in Learning Media Courses. SAP (Order of Educational Articles), 3(1), 1-9. https://doi.org/10.30998/sap.v3i1.2728

Andri, RM (2017). The Role and Function of Technology in Improving the Quality of Learning.

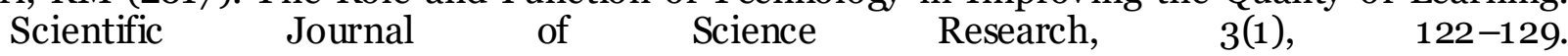
http://www.jurnalmudiraindure.com/wp-content/uploads/2017/o4/

Angelo, TA (1995). Beginning The Dialogue: Thoughts On Promoting Classroom Assessment for Critical Thinking Cooperative Learning and Critical Thinking.

Arikunto, S. (2010). Research Procedure A Practical Approach. Rineka Cipta.

Basyarudin. (2019). Improving the Effectiveness of Social studies Learning Through the Use of Ice Breaker Humor in Class V Sd Negeri 22 Bengkalis. Tambusai Journal of Education, 3(1), 274284.

Bell, S. (2010). Project-Based Learning for the 21st Century: Skills for the Future. The Clearing House: A Journal of Educational Strategies, Issues and Ideas, 83(2), 39-43. https://doi.org/10.1080/00098650903505415

David, E., Sondakh, M., \& Harilama, S. (2017). The Influence of Vlog Content on Youtube on the Attitude Formation of Communication Studies Students. Acta Diurna, 6(1). https://ejournal.unsrat.ac.id/index.php/index/index

Dj, DS (2017). Project-Based Learning Model With Video Media For Physics Learning In High School. LPMP Lampung, 44.

Effendi. (2015). Peer Tutor Type Cooperative Learning Model With Learning Achievement. JPF Journal of Physics Education, University of Muhammadiyah Metro, JPF. Vol., 14-24.

Ennis, RH (1993). Critical thinking assessment. Theory Into Practice, 32(3). https://doi.org/10.1080/00405849309543594

Facione, P.a. (2015). Critical Thinking: What It Is and Why It Counts. In Insight assessment (Issue ISBN 13: 978-1-891557-07-1.). https://www.insightassessment.com/CT-Resources/TeachingFor-and-About-Critical-Thinking/Critical-Thinking-What-It-Is-and-Why-It-Counts/CriticalThinking-What-It-Is-and-Why-It-Counts-PDF

Habók, A., \& Nagy, J. (2016). In-service teachers' perceptions of project-based learning. SpringerPlus, 5(1), 1-14. https://doi.org/10.1186/s40064-016-1725-4

Handayani, AS, \& Dian, D. (2021). Application of Project Based Learning Learning Model Assisted by Video Learning to Increase Creativity in Artwork in Class II Students of SDN 2 Sungapan. 1293-1303.

Hasan, \& Kazazi, NG (2014). Hassan \& Kazazi. NG (2014). Critical Thinking and Writing: The Effects of Critical Thinking on Writing Skill among Iranian University Students Majority in TEFL. International Journal of Language Learning and Applied Linguistic World (IJLLALN), 5(4), 254-266.

Insy asiska, D., Zubaidah, S., \& Susilo, H. (2015). The Effect of Project Based Learning on Learning Motivation, Creativity, Critical Thinking Ability, and Student Cognitive Ability in Biology Learning. Journal of Biological Education, 7(1), 9-21. https://doi.org/10.17977/umo52v7i1p921

Jaenudin, R. (2014). The Concept of Social Science in the Education System in Indonesia. Journal of Social Forums, VII(1), 440-451.

Kemenristekdikti. (2014). National Higher Education Standards. Educational Standards, 49, 2123. content/uploads/2014/o6/permen_tahun2014_nomoro49.pdf

Ledward, BC, \& Hirata, D. (2011). An Overview of 21st Century Skills. Summary of 21 st Century skills for students and teachers, pacific policy research center. In Honolulu: Kamehameha Schools-Research \& \& Evaluation. http://www.ksbe.edu/spi/PDFS/21st\%25/20Century\%2520Skills\%2520Brief.pdf

Lugiati, L. (2020). Using Project-Based Learning Model Using Audio Video to Improve Student Learning Outcomes. Journal of Education Action Research, 4(4), 481. https://doi.org/10.23887/jear.v4i4.28645

Mulia, F., \& Mustadi, A. (2019). Improving Critical Thinking Skills of PGSD Students in Science Education Courses Using the Project-Based Learning Model. Education Lantern, 22(1), 52. 
Mustaji, N. (2015). Empowering Students To Think Critical, Creative, And Collaborative Through The Development Of Collaborative Learning Tools. Kwangsan Journal, 3(1), 59. https://doi.org/10.3180o/jurnalkwangsan.v3i1.25

Purba, MSM (2019). Increasing Student Learning Concentration Through Utilization of Quizizz Learning Evaluation in Physical Chemistry Course I. Journal of Educational Dynamics, 12(1), 29. https://doi.org/10.33541/jdp.v12i1.1028

Razaq, AR (2014). To Achieve. PILAR Journal, 2(2), 122-136.

Rosma, F., \& Hasanah, M. (2021). the Effect of the Project-Based Learning Model in Students' Critical Thinking Skills on Environmental Pollution Subjects. BIOTIK: Scientific Journal of Biology, Technology and Education, 9(1), 74. https://doi.org/10.22373/biotic.v9i1.8220

Sani, RA (2013). Scientific Learning for 2013 Curriculum Implementation. Earth Literacy.

Sari, RT, \& Angreni, S. (2018). Implementation of Project-Based Learning (PjBL) Learning Model Efforts to Increase Student Creativity. VARIDIKA Journal, 30(1), 79-83. https://doi.org/10.23917/varidika.v30i1.6548

Sugiyono. (2016). Quantitative, Qualitative and R\&D Research Methods. Alphabet.

Supardi. (2012). Fundamentals of Social Sciences. Wave.

Suradji, M. (2018). Development of Information and Communication Technology in Student Affairs, Personnel and Finance at Muhammadiyah 1 Gresik High School. Journal of Islamic Education Studies, 1(2), 127-151.

Suryahdikusumah, AR (2018). Project-Based Learning To Develop Student Creativity Designing Educational Media Information Through Social Media. Innovative Counseling:Theory, Practice, and ..., 94-100. http://umtas.ac.id/journal/index.php/innovative_counseling/article/view/259

Susanawati, E., Diantoro, M., \&Yuliati, L. (2013). The Influence of Project-Based Learning Strategy with Thinkquest on Critical Thinking Ability in Physics Students of SMA Negeri 1 Kraksaan. UPI Journal, 18(2). http://jurnal.upi.edu/2875/view/2114/influence-strategy-project-basedlearning-with-thinkquest-against-ability-critical-thinking-physics-siswa-sma-negeri-1kraksaan-.html

Turner, ET (2012). Meeting Learners' Needs through Project-Based Learning. International Journal of Adult Vocational Education and Technology, 3(4). https://doi.org/https://doi.org/10.4018/javet.2012100103

Utomo, SW, \& Wihartanti, LV (2019). Application of Blended Learning Strategy to Improve Students' Critical Thinking Ability in the Industrial Revolution 4.0 Era. Kwangsan: Journal of Educational Technology, 7(1), 30-44. https://doi.org/10.31800/jtp.kw.v7n1.p30--44

Wahyuni, S., Susetyarini, RE, \& Latifa, R. (2015). LESSON ST UDY (Lesson Study is conducted by a group of Biology Education Study Program lecturers. JINoP (Journal of Learning Innovation), 1(2), 187-200.

Warsito, B. (2008). Foundational Learning Technologies \& Their Applications. Rineka Cipta.

Yunita, S., Rohiat, S., \& Amir, H. (2018). Analy sis of Critical Thinking Ability in Chemistry Subjects in Xi Ipa Class Students of SMAN 1 Kepahiang. Ejournal.Unib.Ac.Id, 2(2), 33-38. https://ejournal.unib.ac.id/index.php/alotropjurnal/article/view/4628

Zubaidah, S. (2010). Think critically: Higher Order Thinking Skills That Can Be Developed Through Science Learning. National Science Seminar 2010 With the Theme "Optimizing Science to Empower Humans," January 2010, 11. 